\title{
Mutation in the HTRA1 Gene in a Patient with Degenerated Spine as a Component of CARASIL Syndrome
}

\author{
CARASIL Sendromunun Bir Unsuru Olarak Dejenere Omurgası Olan
} Bir Hastada HTRA1 Gen Mutasyonu

\author{
Fatih BAYRAKLI ${ }^{1}$, Hatice BALABAN² ${ }^{2}$, Mustafa GURELIK ${ }^{1}$, Sami HIZMETLI ${ }^{3}$, Suat TOPAKTAS ${ }^{2}$ \\ ${ }^{1}$ Cumburiyet University, Faculty of Medicine, Department of Neurosurgery, Sivas, Turkey \\ ${ }^{2}$ Cumburiyet University, Faculty of Medicine, Department of Neurology, Sivas, Turkey \\ ${ }^{3}$ Cumburiyet University, Faculty of Medicine, Department of Physical Therapy and Rehabilitation, Sivas, Turkey
}

This work is supported by a Scientific Research Project Fund of Cumburiyet University under project number T-447.

Corresponding Author: Fatih BAYRAKLI / E-mail: fbayrakli@hotmail.com, fbayrakli@cumhuriyet.edu.tr

\begin{abstract}
AIM: To show the mutation in HTRA1 gene in a patient suffering from CARASIL syndrome with degenerated spine as a component of the disease.

MATERIAL and METHODS: We identified a family that one of the members had CARASIL syndrome in eastern Turkey and collected venous blood from available persons. The HTRA1 gene sequenced in all family members.

RESULTS: $C$ to $T$ transition at position 1108 (c.1108 C>T) in exon 6, causing stop codon formation (R370X) was seen in the HTRA1 gene in a homozygous state in the CARASIL patient whereas it was heterozygous in other healthy family members.

CONCLUSION: We demonstrated homozygous C.1108 C>T mutation in the HTRA1 gene causing a very rare syndrome, especially in the nonJapanese population, called CARASIL. Patients with degenerated spine and progressive clinical symptoms must be evaluated or reevaluated for other central nervous system symptoms and signs to rule out other diseases or syndromes.
\end{abstract}

KEYWORDS: Degenerated spine, HTRA1, CARASIL, Mutation

öz

AMAÇ: CARASIL sendromu barındıran ve hastalığın bir unsuru olarak dejenere omurgası olan hastada HTRA1 genindeki mutasyonu göstermek. YÖNTEM ve GEREÇLER: Bireylerinden birinde CARASIL sendromu olan aileyi doğu Türkiye'de bulduk ve varolan tüm bireylerden venöz kan aldık. Tüm aile bireylerinde HTRA1 geni dizilendi.

BULGULAR: Genin 6. ekzonunda 1108. pozisyonda C'den T'ye (c.1108 C>T) stop kodon oluşumuna yol açan (R370X) değişim görüldü. Bu değişim hasta bireyde homozigot, diğer aile bireylerinde heterozigot durumdaydı.

SONUÇ: Japon popülasyonu dışında çok nadir görülen ve CARASIL olarak adlandırılan bir sendroma neden HTRA1 geninde homozigot c. 1108 C > T homozigot mutasyonu gösterdik. Dejenere omurgası olan ve ilerleyici klinik semptomları bulunan hastalar santral sinir sisteminin diğer semptom ve ve bulguları farklı bir hastalık ve sendromunun olup olmadığını ortaya koymak için değerlendirilmeli ve tekrar muayene edilmelidir.

ANAHTAR SÖZCÜKLER: Dejenere omurga, HTRA1, CARASIL, Mutasyon

\section{INTRODUCTION}

Degenerative changes can gradually develop in the spine and cause clinical symptoms. This is almost the destiny of our spines and/or possibly the inevitable result of modern medicine that prolonged human life. Degenerative spine disorders constitute a big part of the daily practice of neurosurgeons. Differential diagnosis of the symptoms and signs of the patients with degenerated spine and association of the clinical picture to the degenerated spine is mandatory in most cases.
Cerebral autosomal recessive arteriopathy with subcortical infarcts and leukoencephalopathy (CARASIL) is characterized by nonhypertensive cerebral small-vessel arteriopathy with subcortical infarcts, alopecia, and spondylosis. Onset is generally in early adulthood and the disorder is associated with mutations in the HTRA1 gene $(1,2)$.

Most of the reported CARASIL cases have originated in Japan and China, but there is a case report from the Caucasian population in the literature (3). 
We report a Turkish patient who suffered degenerative spine signs and symptoms although she had been operated on. The clinical picture got worse and a diagnosis of CARASIL syndrome was made after careful clinical reevaluation. She also harbored a truncating HTRA1 mutation.

\section{CASE REPORT}

A 29-year-old single woman who was suffering from back and neck pain, right-sided weakness and difficulty in walking for two years was referred to our department. She had been operated for lumbar degeneration and instability two years ago but experienced progression in her symptoms and signs especially in walking after the operation.

Neurological examination revealed right-sided hemiparesis and, right-sided increased deep tendon reflexes in the upper and lower extremities. Extensor plantar responses and Hoffman reflexes were present bilaterally. Cognitive functions of the patient were normal, and her physical examination revealed alopecia and no hypertension (Figure $1 \mathrm{C}$ ). The patient's parents were first-degree cousins and there was no family history of CARASIL disease (Figure 1A).

Cervical and lumbar magnetic resonance imaging (MRI) of the patient revealed widespread degenerative spine findings at multiple levels (Figure 1D-E). An MRI of the brain revealed bilateral diffuse white matter lesions that were hypointense on the T1-weighted images and hyperintense on the T2weighted images (Figure 1G). The white matter of bilateral temporal poles showed hyperintensity on T2-weighted MRI. In addition, multiple small infarcts were seen in the brain stem, thalamus, and periventricular white matter (Figure 1F). Based on the clinical features and these MRI findings, the diagnosis was CARASIL.

The study was approved by the Cumhuriyet University Committee of Assessment of Scientific Research (Protocol number: 10/180). Our family was from eastern Turkey.

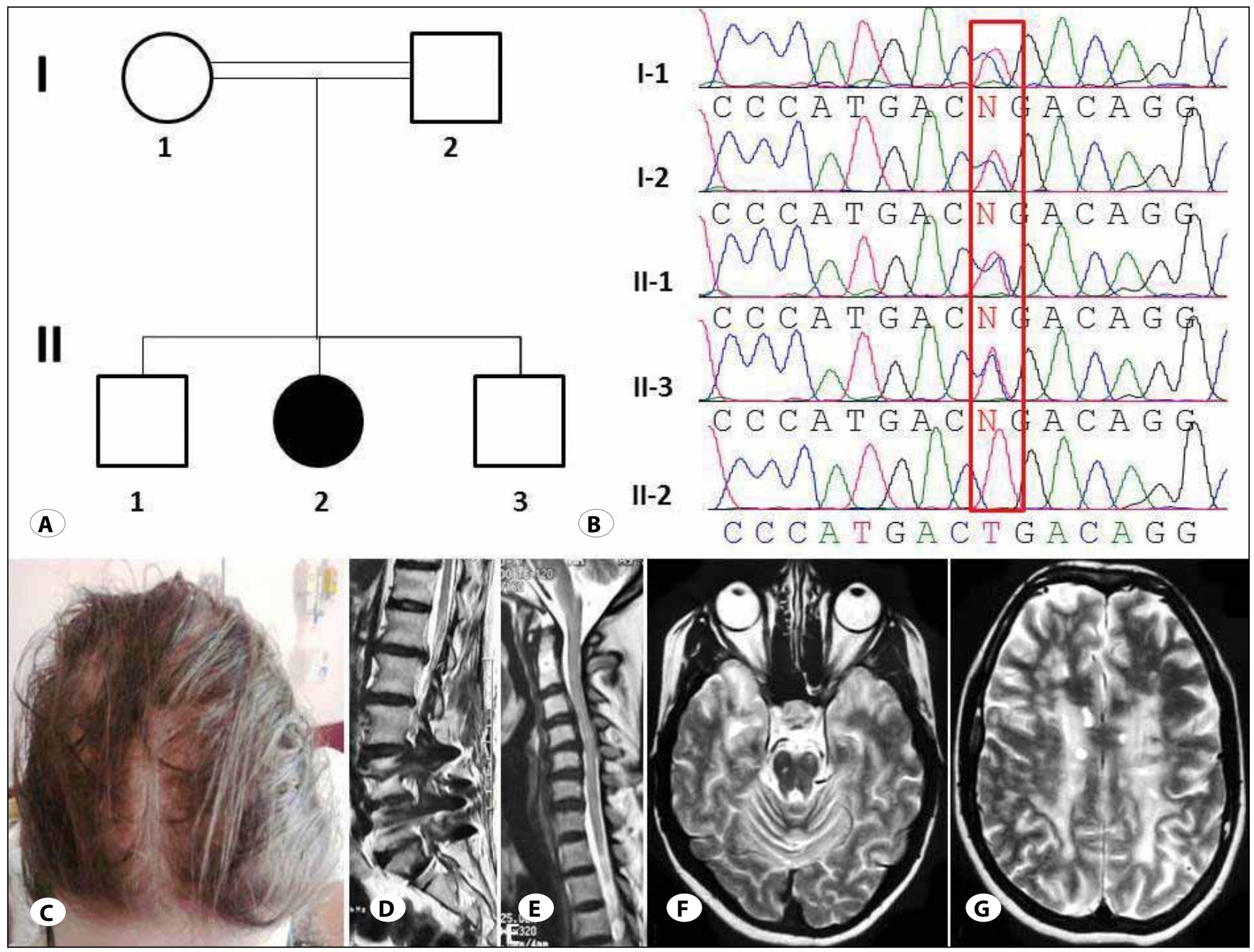

Figure 1: A) Pedigree of the family; black symbol indicates complete CARASIL phenotype; parents are first-degree cousins. B) Sequencing of all family members in exon 6 of HTRA1 revealed c.1108 C>T transition, leading arginine to stop codon (R370X) and causing truncation in the protein. C) The proband showed alopecia. D) Cervical spine degeneration on midsagittal MRI. E) Lumbar degeneration and artifacts because of undergone stabilization operation. F-G) Brain axial sections revealed widespread white matter changes involving anterior temporal lobes, centrum semiovale, and brain stem. 
The family had a patient with CARASIL syndrome based on clinical, radiological and medical records. Blood samples were collected from all family members after the attainment of informed consent. Total genomic DNA was isolated according to standard protocols.

Exon-intron boundaries of the HTRA1 gene were determined based on the University of California at Santa Cruz (UCSC) Genome Browser (http://genome.ucsc.edu/). PCR primers were designed using PRIMER3 (http://frodo.wi.mit.edu/ primer3/). All known exons were amplified and sequenced for each family member using standard techniques.

Sequencing of all exons of the HTRA1gene in all the family members revealed a homozygous $C$ to $T$ transition at position 1108 (c.1108 C>T) in exon 6, causing stop codon formation (R370X) in the CARASIL patient. The heterozygous C.1108 C>T mutation was found in both parents and also two brothers (Figure 1B).

\section{DISCUSSION}

Fukutake and Hirayama (1) reported the first review of 17 Japanese CARASIL patients and concluded that confinement to Japanese patients is one of the features of this syndrome. Zheng et al. (5) reviewed two CARASIL patients from the same family from China, who were the first CARASIL cases reported outside Japan. Mendioroz et al. (3) expanded the disease phenotype to a Caucasian family with Spanish ancestry. We report a Turkish patient who is to our knowledge the third CARASIL case in the literature reported outside the Japanese population.

The HTRA 1 gene encodes a member of the trypsin family of serine proteases. This protein is a secreted enzyme that is proposed to regulate the availability of insulin-like growth factors (IGFs) by cleaving IGF-binding proteins. It has also been suggested to be a regulator of cell growth.

Mammalian HTRA1 contains an $\mathrm{N}$-terminal domain of unknown function, a serine protease domain and one C-terminal PDZ domain. HTRA1 is ubiquitously expressed, plays important physiological roles and is associated with diseases such as arthritis, cancer, familial ischemic cerebral small-vessel disease, age-related macular degeneration, and Alzheimer's disease (4). The mutation in our case was located at the beginning of the PDZ domain, which is necessary for substrate processing (4). There is not much known about how HTRA1 gene malfunctions cause spine degeneration in literature, but what is known about HTRA1 mutations is that it causes vasculopathy. This fact may open a new era on spine degeneration pathogenesis showing that involvement of vessels that supply the spine by a pathology for any reason may cause spine degeneration.

We believe that CARASIL could be more widespread throughout the world in different races. The disease incidence is possibly low because the patients are receiving wrong diagnoses.

\section{CONCLUSIONS}

We demonstrated a mutation in the HTRA1 gene in a CARASIL patient with degenerated spine. Patients with degenerated spine, progressive clinical symptoms, and young adulthood onset of symptoms must be evaluated or reevaluated for other central nervous system symptoms and signs to rule out other disorders and for early diagnosis of the CARASIL syndrome.

\section{REFERENCES}

1. Fukutake T, Hirayama K: Familial young-adult-onset arteriosclerotic leukoencephalopathy with alopecia and lumbago without arterial hypertension. Eur Neurol 35: 69-79, 1995

2. Hara K, Shiga A, Fukutake T, Nozaki H, Miyashita A, Yokoseki A, Kawata H, Koyama A, Arima K, Takahashi T, Ikeda M, Shiota $H$, Tamura M, Shimoe $Y$, Hirayama M, Arisato T, Yanagawa $S$, Tanaka A, Nakano I, Ikeda S, Yoshida Y, Yamamoto T, Ikeuchi T, Kuwano R, Nishizawa M, Tsuji S, Onodera O: Association of HTRA1 mutations and familial ischemic cerebral small-vessel disease. N Engl J Med 360: 1729-1739, 2009

3. Mendioroz M, Fernandez-Cadenas I, Del Rio-Espinola A, Rovira A, Sole E, Fernandez-Figueras MT, Garcia-Patos V, Sastre-Garriga J, Domingues-Montanari S, Alvarez-Sabin J, Montaner J: A missense HTRA1 mutation expands CARASIL syndrome to the Caucasian population. Neurology 75: 20332035, 2010

4. Truebestein L, Tennstaedt A, Mönig T, KrojerT, Canellas F, Kaiser $M$, Clausen T, Ehrmann M: Substrate-induced remodeling of the active site regulates human HTRA1 activity. Nat Struct Mol Biol 18: 386-388, 2011

5. Zheng DM, Xu FF, Gao Y, Zhang H, Han SC, Bi GR: A Chinese pedigree of cerebral autosomal recessive arteriopathy with subcortical infarcts and leukoencephalopathy (CARASIL): Clinical and radiological features. J Clin Neurosci 16: 847-849, 2009 